\title{
Durational Residence Requirements for Public Employment
}

Durational residence requirements condition certain governmental benefits and privileges upon residence within a state or locality for a specified period of time. Some states and localities have made such requirements a prerequisite for public employment. Two key governmental interests advanced for these requirements are: (1) allocating employment opportunities to longer-term, bona fide, or uneinployed residents, ${ }^{1}$ and (2) controlling population growth. ${ }^{2}$ The imdividual's imterest in public employment, interstate travel, and equal protection oppose the governmental interests.

The United States Supreme Court has yet to rule on the constitutionality of durational residence requirements for public employinent. The Court has faced similar requirements im other contexts, beginning in 1969 with Shapiro v. Thompson, ${ }^{3}$ in which it struck down a one-year waitimg period for welfare benefits. ${ }^{4}$ Simce then the Court lias invalidated durational residence requirements for voting ${ }^{5}$ and free nonemer-

1. See, e.g., Hicklin v. Orbeck, 565 P.2d 159 (Alas. 1977), rev'd on other grounds, 437 U.S. 518 (1978).

2. See Nehring v. Ariyoshi, 443 F. Supp. 228, 238 (D. Hawaii 1977) (rejecting both rationales). See also note 15 infra.

3. 394 U.S. 618 (1969).

4. Because welfare benefits were denied to those who had migrated to the state within the previous year, the residence requirement "penalized" the exercise of the right to travel. The Court found the governmental interests asserted in support of the requirement to be either inpermissible or not compelling. Id. at 627. Found constitutionally impermissible were: (1) deterrence of the immigration of indigents generally; (2) deterrence of the immigration of those who came to achieve higher benefits; and (3) distimctions between old and new residents on the basis of tax contribution to the community. Id. at 629-33. "Administrative and related governmental objectives" found permissible but not compelling were: (1) aiding budget plannimg; (2) providing an objective test of residency; (3) prevention of fraud; and (4) encouraging new residents to enter the labor force. Id. at 633-38.

The Court noted that it expressed no view about the validity of other durational residence requirenents. "Such requirenents may promote compelling state interests on the one hand, or, on the other, nray not be penalties upon the exercise of the constitutional right of interstate travel." Id. at $638 \mathrm{n} .21$.

On the welfare issue itself, there were several developments in the aftermath of Shapiro. The Court rejected the arguinent that Shapiro was apphicable only to federally-funded welfare programs im Pease v. Hansen, 404 U.S. 70 (1971). Lower courts struck down durational residence requirentents in various public assistance programs, imcluding state relief, aid to the disabled, old age assistance, and aid to physically handicapped children. See Note, Durational Resldence Requirements from Shapiro Through Sosna: The Right to Travel Takes a New Turn, 50 N.Y.U.L. REv. 622, 634 (1975), and cases cited therein. Shapiro was extended to cover residency requirements for admission to public housing in King v. New Rochelle Mun. Hous. Auth., 442 F.2d 646 (2d Cir.), cert. denied, 404 U.S. 863 (1971) and Cole v. Housing Auth., 435 F.2d 807 (1st Cir. 1970).

5. Congress abolished state durational residency requirements for presidential elections by 
gency medical services ${ }^{6}$ but upheld such requirements for divorce filing, ${ }^{7}$ tuition benefits at public colleges and universities, ${ }^{8}$ admission to the bar, ${ }^{9}$ and candidacy for public office. ${ }^{10}$

enacting $\$ 202$ of the Voting Rights Act of 1970, 42 U.S.C. \& 1973aa-1 (1970). The Supreme Court upheld this provision in Oregon v. Mitchell, 400 U.S. 112 (1970), with at least six justices invoking some form of the right to travel. $I d$. at 237-38, 286-87.

In Dunn v. Blumstein, 405 U.S. 330 (1972), the Court struck down Tennessee's residency requirements for voting eligibility. The restrictions struck down were one-year (state) and threemonth (county) requirements. The Court recognized the need for a 30-day waiting period to facilitate administration and prevent fraud. Id. at 348. Subsequently the Court upheld a 50-day waiting period, noting that this duration approached the outer constitutional limits. Unlike the residency requirements in Dunn, however, these periods coincided with the closing of registration for everyone. Burns v. Forston, 410 U.S. 686, 687 (1973) (per curiam); Marston v. Lewis, 410 U.S. 679 (1973).

6. In Memorial Hosp. v. Maricopa County, 415 U.S. 250 (1974), the Supreme Court struck down Arizona's one-year residence requirement for county-funded nonemergency inedical care. The court noted the validity of bona fide residence requirements, id. at 255 , but held that the durational residence requirement "creates an 'invidious classification' that inipinges on the right of interstate travel by denying newcomers 'basic necessities of life.' "Id., at 269. Applying strict scrutiny, the Court rejected numerous justifications for the requirement. As in Shapiro, the Court rejected the purposes of (1) deterring immigration of indigents generally; (2) deterring indigents from taking up residence in the county solely to use the medical facilities; and (3) protecting longtime residents who had paid taxes in the community. Id. at 263-66. The Court also rejected the argument that the one-year waiting period is a convenient rule of thumb to determine bona fide residence. Id. at 267.

7. Sosna v. Iowa, 419 U.S. 393 (1975), upheld a one-year state residence requirement for divorce, distimguishing it from those rejected in previous cases. First, the Court found the individual interest in travel less burdened than in the previous cases because benefits were only delayed, not permanently lost. Id. at 406 . Second, the state's interests in the residence requirement for divorce-protection of spouses and children, avoidance of conflicts with other states, and protection of divorce decrees from collateral attack-were stronger than the "budgetary or recordkeeping considerations" advanced in Shapiro, Dunn, and Memorial Hospital. Id. at 406-07.

8. Sturgis v. Washington, 368 F. Supp. 38 (W.D. Wash. 1973) (three-judge court), aff $d$ mem., 414 U.S. 1057 (1973); Starns v. Malkerson, 326 F. Supp. 234 (D. Minn. 1970) (three-judge court), affd mem., 401 U.S. 985 (1971); Kirk v. Regents of the Univ. of Cal., 273 Cal. App. 2d 430, 78 Cal. Rptr. 260 (1st Dist. 1969), appeal dismissed, 396 U.S. 554 (1970).

In Vlandis v. Kline, 412 U.S. 441 (1973), the Court held a state could not deny an individual the opportunity to present evidence that he or she is a bona fide resident entitled to resident tuition rates, by an irrebuttable presumption of nonresidence which continued for the entire period of attendance at the university. Id. at 452 . The opinion did suggest, however, that a state could inpose as one element in demoustrating bona fide residency a "reasonable durational residency requirement, which can be met while in student status." Id. See also Montgomery v. Douglas, 388 F. Supp. 1139, 11141 (D.Colo. 1974), affd mem., 422 U.S. 1030 (1975).

9. In Rose v. Bondurant, 409 U.S. 1020 (1972), aff $g$ mem., Suffling v. Bondurant, 339 F. Supp. 257 (D.N.M.1972) (three-judge court), the Supreme Court summarily affirmed a federal district court decision upholding a six-month residence requirement for admission to the New Mexico state bar. The district court had concluded that the requirement was "reasonable" and did not unduly penalize petitioners' right to interstate travel. $339 \mathrm{~F}$. Supp. at 260 . Moreover, it was distinguishable from invalid durational residence requirements in that the state had a compelling interest in the quality and integrity of those it licensed to practice law. Moreover, no applicant in the case had undergone any economic hardship. Id. at 259-60. See generally Annot., 53 A.L.R.3d 1163 (1973).

10. The Court agreed that Alabama had a compelling state interest justifying a one-year 
The Court has upheld local police and fire department residence requirements which demand only that a person reside im the state or locality at the time of employment or application for employment, ${ }^{11} \mathrm{em}-$ phasizing the distinction between nondurational and durational residence requirements. ${ }^{12}$ The Court's decision in Hicklin v. Orbeck, ${ }^{13}$ however, struck down a statewide nondurational residence requirement for public-related einployment. ${ }^{14}$

Lower courts have overwhelmingly invalidated state ${ }^{15}$ and lo-

residence requirement for circuit court judges. Hadnott v. Amos, 320 F. Supp. 107 (M.D. Ala. 1970) (three-judge court), affd mem., 401 U.S. 968 (1971). The compelling interest was exposing the candidate to the voters for a substantial period of time before the election. 320 F. Supp. at 121 . Accord, Sununu v. Stark, 383 F. Supp. 1287 (D.N.H. 1974) (three-judge court), affd mem., 420 U.S. 958 (1975) (state senators); Chimento v. Stark, 353 F. Supp. 1211 (D.N.H. 1973) (three-judge court), affd mem., 414 U.S. 802 (1973) (seven-year residence requirement for governor). Although the Court decided Chimento and Sununu after Dunn invalidated durational residence requirements for voting, 405 U.S. 330 (1972), it failed to give the issue plenary treatment. The lower courts remain split, see, e.g., Henderson v. Fort Worth Indep. School Dist., 526 F.2d 286 (5th Cir. 1976) (requirement for local school board struck down). Thus, the constitutional status of this type of durational residence requirement is unsettled.

11. These are also known as "pure" or "bona fide" or "contimuous" residence requirements.

12. In McCarthy v. Philadelphia Civil Serv. Comm'n, 424 U.S. 645, 646-47 (1976) (per curiain), the Court upleld a mumcipal ordmance requiring that firefighters be city residents. The Court poimted out that those cases did not imvolve "a public agency's relationship with its own employees which, of course, may justify greater control than that over the citizenry at large." Id. at 646 n.6. The Court concluded that contmuous residence requirements were not "irrational." Id. at 646 .

See also Detroit Police Officers Ass'n v. City Council, 385 Mich. 519, 190 N.W.2d 97 (1971), appeal dismissed, 405 U.S. 950 (1972). The Michigan court had leld that the ordinance requiring police officers to be city residents did not violate equal protection. The opinion stressed the special characteristics that distinguish police employees from other city employees. Id. at 522-23, 190 N.W.2d at 97-98.

13. 437 U.S. 518 (1978).

14. The Alaska Hire Law required that all oil and gas leases, easements, or right-of-way permits for oil or gas pipelines favor qualified Alaska residents in employment. Id. at 520. The law also contained a one-year durational residence provision, which the Alaska Supreme Court struck down, Hicklin v. Orbeck, 565 P.2d 159, 165 (Alas. 1977), but which was not considered on appeal. 437 U.S. at 522 n.60.

The Court struck down the nondurational residence provision on privileges and immunitics grounds. The Court emphasized prior decisions holding that "state discrimmation against nonresidents seeking to ply their trade, practice, their occupation, or pursue a common calling within the State" violated the privileges and immunities clause of artiele $1 \mathrm{~V}$, scction 2 of the Constitution. Id. at 524. Alaska failed to slow that nonresidents were a peculiar source of high unemployment, or that discrimination against nonresidents bore a substantial relationship to unemployment. $I d$. at $526-28$.

15. In Nehring v. Ariyoshi, 443 F. Supp. 228 (D. Hawaii 1977), the federal district court struck down a Hawaii statute that placed a one-year state residence requirement on applicants for state and local government jobs. It mled that the statute violated the federal equal protection clause, since the state failed to establish a compelling interest or even a rational basis for it. The court said the statute was "clearly not tailored to aehieve the allocation of employment to longterm residents, id. at 239; nor was it needed to control growtl and protect Hawaii's unique island environment, id. at 238-39. See text accompanying notes 85-87 infra.

In York v. State, 53 Hawain 557, 498 P.2d (1972), the Hawaii Supreme Court invalidated a 
$\mathrm{cal}^{16}$ residence requirements for government employment, private employment on public projects, ${ }^{17}$ and veterans' preferences in public employment. ${ }^{18}$ One court has upheld a durational residence preference for local police employment. ${ }^{19}$

The Burger Court's ambivalence toward durational residence requirements in general and its growing disenchantment with the equal protection analysis of Shapiro and its progeny, ${ }^{20}$ however, leave open

three-year residence requiremeut for state and local government employment. The court rejected the state's contention that employees with three years of residence would better know local customs and thus provide better service. Id. at 560-61 \& n.3, 498 P.2d at 646-47 \& n.3.

See also State v. Wylie, 516 P.2d 142 (Alas. 1973) (personnel rules giving an absolute hiring preference to one-year Alaska residents violated equal protection). Alaska's justifications-reducing imemployment, upgrading and better utilizing state human resources, and improving the efficieucy of state government-did not meet the compelling state interest test. The court distinguished nondurational residence requirements. Id. at 150 .

In Justice v. Manzagol, No. 74-611 (D.N.M. Jan. 20, 1976) (unpublished decision), the federal district court held that New Mexico's statute requiring one-year residence for all state nonprofessional employees imposed an impermissible burden on the right of interstate travel. The court rejected the state's justifications of promoting a stable civil service system, assuring government employee familiarity with New Mexico customs, rewarding prior state taxpayers, and favoring "bona fide" state residents. The court said the residence requirement helped the unemployment situation "only by fencing out the competition from other States," which was an impermissible restraint on the right of interstate travel.

16. In Jenkins v. McCollum, 446 F. Supp. 667 (N.D. Ala. 1978), a federal district court held that Tuscaloosa County conld not require any period of prior county residence for a federally fuuded county position. The court said that such a requirement violated the "right of unobstructed travel," one of the privileges and immumities of a United States citizen. Id. at 671 .

In Eggert v. City of Seattle, 81 Wash. 2d 840, 505 P.2d 801 (1973), the Washington Supreme Court leld that a city charter provision that favored one-year city or county residents for city employment infringed the right to travel and violated equal protection. The requirement penalized the right to travel by denying even bona fide residents who had recently urigrated to the city the right to compete for employment on an equal basis. The court said the state failed to show any compelling interest for the provision.

17. In People ex rel. Holland v. Bleigh Constr. Co., 61 III. 2d 258, 335 N.E.2d 469 (1975), the Illinois Supreme Court struck down a one-year durational residence preference for einployment on public works projects. Accord, Salla v. County of Monroe, 90 Misc. 2d 427, 395 N.Y.S.2d 366 (Sup. Ct. 1977), affd sub nom. Lisbon Contractors, Inc. v. County of Monroe, 43 N.Y.2d 985, 375 N.E.2d 1232, 404 NY.S.2d 843 (1978) (holding the residency preference violated the privileges and immunities and commerce clauses as well as equal protection). See also Hicklin v. Orbeck, 565 P.2d 159 (Alas. 1977), rev'd on other grounds, 437 U.S. 518 (1978).

18. Carter v. Gallagher, 337 F. Supp. 626 (D. Minn. 1971); Stevens v. Campbell, 332 F. Supp. 102 (D. Mass. 1971).

19. Town of Milton v. Civil Serv. Comm'n, 365 Mass. 368, 312 N.E.2d 188 (1974). The court leld that the effectiveness of police service was a compelling state imterest. Also, residence in the city was found to bear a substantial relation to job perfornance. Id. at 374-76, 312 N.E.2d at 194 95. The court stressed that the case involved a preference rather than an outright derial of employment. Id. at 373-74, 312 N.E.2d at 193. One commentator suggests that the case can be cxplained by the courts' usual deference to state interests concerning police qualifications. See Note, supra note 4, at 636 n.97. A federal district court said Milton applied only when "the particular requirement of a specified job supports a compelling interest." CDR Enterprises, Ltd. v. Board of Educ., 412 F. Supp. 1164, 1170 (E.D.N.Y. 1976), affd mem. sub nom Lefkowitz v. CDR Enterprises, Ltd., 429 U.S. 1031 (1977).

20. See part I infra. 
the possibility that such requirements for public employment ultimately may be upheld.

This Comment argues that durational residence requirements for public employment are unconstitutional. Part I discusses an appropriate standard of judicial review of these requirements. It argues that since they significantly burden or penalize the right to travel, strict scrutiny is appropriate. Part II argues that under strict scrutimy or even undcr an intermediate "substantial relation" test, the governmental interests in einployment allocation or growth control do not justify the burdening of certain constitutional rights.

\section{INDIVIDUAL INTERESTS AND THE STANDARD OF REVIEW}

Simce Shapiro, durational residence requirements have been challenged primarily under the equal protection clause of the United States Constitution. ${ }^{21}$ The challengers usually allege a violation of their constitutional right to travel. ${ }^{22}$ The validity of the requirements usually depends upon the equal protection standard of scrutimy that is applied. ${ }^{23}$ The critical first step, therefore, is to derive from precedent the appropriate standard of review. ${ }^{24}$

\section{A. Equal Protection Analysis Generally}

During the Warren Court's latcr years, a "two-tier" equal protection scleme ennerged: either a traditional, permissive "rational rela-

21. See Note, supra note 4, at 623.

22. In Shapiro, the Court expressed the following view of this right:

[The] right finds no explicit mention in the Constitution. The reason, it has been suggested, is that a right so elementary was conceived from the beginning to be a necessary concomitant of the stronger Union the Constitution created. In any event, freedom of travel throughout the United States lias long been recognized as a basic right under the Constitution.

Shapiro v. Thompson, 394 U.S. 618, 630-31 (1969) (quoting Umited States v. Guest, 383 U.S. 745, 758 (1966)). Justice Stewart advocated an imdependent treatunent of the right to travel. In his view, the right "is not a mere conditional hiberty subject to regulation and control under conventional due process or equal protection standards." It preceded the fourteenth amendment and finds constitutional protection apart from it; like the right of association, it is a "virtually unconditional personal right." 394 U.S. at 642-43 (Stewart, J., concurring).

23. The standard is not always decisive, lowever. Durational residence requirements for candidates lave been upheld even under the compelling state interest test, See, e.g., Hadnott v. Amos, 320 F. Supp. 107 (M.D. Ala. 1970), affd mem., 401 U.S. 968 (1971). Likewise, others have been struck down under the rational relation test. See Cole v. Housing Auth., 435 F.2d 807, 813 (1st Cir. 1970) (public housing); Webster v. Wofford, 321 F. Supp. 1259, 1261-62 (N.D. Ga. 1970) (bar admission). See also Hanson v. Unified School Dist., 364 F. Supp. 330, 332-34 (D. Kan. 1973) (nondurational residence requirement for employment held violative of equal protection under rational relation test).

24. This Comment does not evaluate such requirements under due process, privileges and immunities, or commerce clause theories. 
tion" standard or "strict scrutiny" is selected. ${ }^{25}$ The former typically applies where ordinary economic or social legislation is challenged. Under it, the challenger must prove that the legislation's means are not rationally related to its objects. Strict scrutiny apphes where a statute creates a "suspect classification" or affects a "fundainental right." Then the state inust show that the legislation's classification furthers a "coinpelling state interest" and that the means chosen are precisely "tailored" to minimize the burden on constitutional rights.

The Burger Court has hesitated to expand strict scrutiny, but it sometimes has been willing to provide greater scrutiny than the traditional rational basis test requires. ${ }^{26}$ Its approach has been viewed as a movernent toward an intermediate equal protection test. ${ }^{27} \mathrm{~A}$ federal district judge described it as follows:

In recent years, the Supreme Court has apparently been less willing to accord even those statutes involving non-fundamental, non-suspect categories the virtually automatic approval that such legislation had historically enjoyed. The Court has indicated that a statute creating any classification must at least "be reasonable, not arbitrary, and must rest upon some ground of difference having a fair and substantial relation to the object of the legislation, so that all persons similarly circumstanced shall be treated alike. ${ }^{28}$

This "substantial relation" test focuses on means rather than ends. While the purposes of the classification need only be legitimate, the means must bear a substantial relation to those purposes. ${ }^{29}$ lows:

A three-tier approach may be summarized schematically as fol-

25. See generally G. Gunther, Constrtutional Law: CASES AND MATERIALs 657-63 (9th ed. 1975); Gunther, The Supreme Court, 1971 Term-Foreword: In Search of Evolving Doctrine on a Changing Court: A Model for a Newer Equal Protection, 86 HARV. L. Rev. 1 (1972); Note, supra note 4 , at $623-29$.

26. See G. GUNTHER, supra, note 25 , at 659-60.

27. Justice Marshall has suggested that the Court's approach to equal protection analysis is a sliding scale with "variations in the degree of care with which the Court will scrutinize particular classifications, depending . . . on the constitutional and societal inportance of the interest adversely affected and the recognized invidiousness of the basis upon which the particular classification is drawn." San Antonio School Dist. v. Rodriguez, 411 U.S. 1, 98-99 (1973) (Marshall, J., dissenting).

28. Norwick v. Nyquist, 417 F. Supp. 913, 917 n.7 (S.D.N.Y. 1976) (Couner, J.) (citations omitted), prob. juris. noted, 436 U.S. 902 (1978). The substantial relation test is typically cited to Reed v. Reed, 404 U.S. 71, 76 (1971).

29. G. GUNTHER, supra note 25 , at 662 . 


\begin{tabular}{|c|c|c|}
\hline Standard of Review & $\frac{\text { Validity of }}{\text { Purpose }}$ & $\begin{array}{l}\text { Relationship Between } \\
\text { Means and Purpose }\end{array}$ \\
\hline Strict Scrutiny & Compelling & $\begin{array}{l}\text { Precisely tailored, } \\
\text { least drastic means }\end{array}$ \\
\hline Intermediate & $\begin{array}{l}\text { Legitimate or } \\
\text { important }\end{array}$ & Substantial relation \\
\hline Rational Basis & $\begin{array}{l}\text { Legitimate or } \\
\text { permissible }\end{array}$ & Rational rclation \\
\hline
\end{tabular}

\section{B. Right to Travel: Penalty Analysis}

The Burger Court has retained strict scrutiny when a legislative classification "impermissibly interferes with the exercise of a fundainental right." ${ }^{30}$ Though the right of interstate travel has been viewed as a fundamental right, ${ }^{31}$ cases alleging violations of the right have not always triggered strict scrutiny. The Supreme Court has not made it clear which classifications affectimg the right to travel will trigger strict scrutiny. In Shapiro, the Court declared that the right of interstate travel is fundamental and that "any classification which serves to penalize" its exercise inust be justified by a coinpelling governmental interest. $^{32}$ The Court later defined the right as only applying to "migration with intent to settle and abide." 33 However, a "penalty" on the right to travel will trigger strict scrutiny; ${ }^{34}$ actual deterrence of travel need not be proven. ${ }^{35}$

In Memorial Hospital v. Maricopa County ${ }^{36}$ the Court atteinpted to identify a "penalty" on the exercise of interstate travel. At a minimuin, strict scrutiny would be applied where the effect of a requirement would be to burden another fundamental right (e.g., voting) or to deny

30. Massachusetts Bd. of Retirement v. Murgia, 427 U.S. 307, 312 (1976) (citing San Antonio School Dist. v. Rodriquez, 411 U.S. 1, 16 (1973)).

31. Id. at 312, n.3. Other fundamental rights include first amendment rights, the right to vote, the right to procreate, and rights "of a uniquely private nature." Id.

32. 394 U.S. 618, 634, 638 (1969). See also United States v. Guest, 383 U.S. 745,757 (1966).

33. Memorial Hosp. v. Maricopa County, 415 U.S. 250, 255 (1974).

34. Dunn v. Blumstein, 405 U.S. 330, 338-39 (1972). Since durational residence laws "impermissibly condition and penalize the right to travel by imposing their prohibitions on only those persons who have recently exercised that right," they are unconstitutional unless the state can denonstrate that they are "necessary to promote a compelling governmental interest." Id. at 342 (emphasis in original) (quoting Shapiro v. Thompson, 394 U.S. at 634).

35. Tennessee's argunient that its durational residence requirement for voting neither deterred nor was intended to deter travel was rejected in Dunn as follows:

This view represents a fundamental misunderstanding of the law. It is irrelevant whether disenfranchisement or demial of welfare is the more potent deterrent to travel. Shapiro did not rest upon a finding that denial of welfare actually deterred travel. . . . [W] exphicitly stated that the compelling-state-interest test would be triggered by "any classification which serves to penalize the exercise of [the] right [to travel]. . ."."

Id. at 339-40 (quoting Shapiro v. Thompson, 394 U.S. at 634).

36. 415 U.S. 250 (1974). 
a basic necessity of life or a vital government benefit or privilege. ${ }^{37}$ Despite this attempt at clarification, Justice Rehnquist criticized the majority's failure to explam "how to distmguish a waiting period which is a penalty from one which is not."38 Yet, writmg for the majority $\mathrm{m}$ Sosna $v$. Iowa, ${ }^{39}$ he merely distmguished the individual and governmental interests involved in Shapiro, Dunn, and Memorial Hospital. ${ }^{40}$ He neither applied the penalty analysis of those cases nor formulated an alternative approach. ${ }^{41}$

Hence, future evaluation of other durational residence requirements is uncertain. Sosna may involve "interest balancing" or a reversion to thc old deferential equal protection approach. ${ }^{42}$ Or perhaps it indicates that Justices Marshall and Brennan lost control of the dura-

\section{The Court explained:}

Shapiro and Dunn stand for the proposition that a classification which "operates to penalize those persons . . . who have exercised their constitutional right of interstate migration," must be justified by a compelling state interest. Although any durational residence requirement imposes a potential cost on migration, the Court in Shapiro cautioned that some "waiting-period[s] . . . may not be penalties." In Dunn v. Blumstein, supra, the Court found that the denial of the franchise, "a fundamental pohitical right," was a penalty requiring application of the compelling-state-imterest test. In Shapiro, the Court found denial of the basic "necessities of life" to be a penalty. Nonetheless, the Court has declined to strike down state statutes requiring one year residence as a condition to lower tuition at state institutions of higher education.

Whatever the ultimate parameters of the Shapiro penalty analysis, it is at least clear that medical care is as much "a basic necessity of life" to an indigent as welfare assistance. And, governmental privileges or benefits necessary to basic sustenance have often been viewed as being of greater constitutional significance than less essential forms of governmental entitlements.

Id. at 258-59 (citations ormitted). As to such "vital" government benefits and privileges, the Court concluded that the right of interstate travel insures that new residents as well as old enjoy them. Id. at 261.

38. Id. at 284 (dissenting opinion). He proposed two tests: whether the requirement "erects a real and purposeful barrier to movement" and "whether the effects on travel, viewed realisticaly, are merely incidental and remote." Id. at 285 . Thus, he would base the penalty analysis on intent and actual deterrence, an approach rejected in Dunn and Memorial Hospital.

39. 419 U.S. 393 (1975).

40. See note 7 supra.

41. The inajority failed to consider whether divorce was a basic individual right, a necessity of life, or a vital governmental benefit. 419 U.S. at 419-20 (Marshall, J., dissenting). Sosna did, however, introduce a distinction between a durational residence requirement which merely delays receipt of a benefit (e.g., a divorce) and others which pernanently deny a part of what is sought (eg., welfare payinents). See note 56 and accompanying text infra.

42. Indeed, Justice Marshall, author of the majority opimions in Dunn and Memorial Hospital, criticized the Court for its sharp departure from the Shapiro line of cases

The Court's failure to address the case in these terms suggests a new distaste for the mode of analysis we liave apphed to this corner of equal protection law. In its stead, the Court has employed what appears to be an ad hoc balancing test, nnder which the State's putative interest in ensuring that its divorce petitioners establish some roots in Iowa is said to justify the one-year residency requirement. . . .

The Court omits altogether what should be the first inquiry: whether the right to obtain a divorce is of sufficient importance that its denial to recent immigrants constitutes a penalty on interstate travel. . . .

The Court, however, has not ouly declined to apply the "compelling interest" test to this case, it has conjured up possible justifications for the State's restriction in a manner 
tional residence and right to travel issues to a new majority hesitant to expand strict equal protection scrutimy.

If Memorial Hospital's penalty analysis survives Sosna, it requires a determination of the individual interests that constitute "basic necessities of life" or "vital government benefits." While individual interests in voting (Dunn), welfare (Shapiro), and inedical services (Memorial Hospital) have led to invalidation of durational residence requirements, other important interests - divorce, higher education, practice of a profession, and candidacy for public office-have not. Whether such a requirement for public employment is a penalty will hinge on the individual interest in access to such einployinent. The next section will analyze how the Supreine Court should characterize that interest in the face of a durational residence requirement.

\section{Importance of Public Employment}

Does a durational residence requireinent for public einployinent penalize the exercise of the right of interstate travel and, thus, trigger strict scrutiny? It does, if the Court concludes that public employinent is itself a fundaunental right, a basic necessity of life, or a vital governinental benefit or privilege. ${ }^{43}$

While it is now clear that unlimited conditions on public employinent violate due process, ${ }^{44}$ Massachusetts Board of Retirement $v$. Murgia $^{45}$ has held that the right of government employinent is not a fundamental right requiring strict scrutiny. ${ }^{46}$ Murgia does not preclude

much more akin to the lenient standard we have in the past applied in analyzing equal protection challenges to business regulations.

419 U.S. at 419-20 (Marslall, J., dissenting). See also Note, The Right to Travel and Community Growth Controls, 12 HARv. J. LEGIS. 244, 268 (1975).

43. Whether public employment is a right or a privilege has been disputed, but $m$ any event the Supreme Court lias rejected the right-privilege distinction as a basis for constitutional protection. In Shapiro v. Thompson, the Court said that the constitutional challenge there "cannot be answered by the argument that public assistance benefits are a 'privilege' and not a 'right.'" 394 U.S. at 627 n.6. See also Graham v. Richardson, 403 U.S. 365, 374 (1971); Goldberg v. Kelly, 397 U.S. 254, 262 (1970).

44. Purdy \& Fitzpatrick v. State, 71 Cal. 2d 566, 456 P.2d 645, 79 Cal. Rptr. 77 (1969). Since the government cannot abridge constitutional rights by direct action, neither may it condition employment on their surrender. Keyishian v. Board of Regents, 385 U.S. 589, 605 (1967) (first amendment rights). There is also a "federal constitutional right to be considercd for public service without the burden of imvidiously discriminatory disqualifications." Turner v. Fouche, 396 U.S. 346,362 (1970) ("freeholder" requirentent violated equal protection). Even if no abstract right to public employment exists, "constitutional protection does extend to the public servant whose exclusion pursuant to a statute is patently arbitrary or discriminatory." Wieman v. Updegraff, 344 U.S. 183, 192 (1952) (loyalty oath provision for applicants violated due process).

45. 427 U.S. 307 (1976).

46. The Murgia Court aplied the rational test and upheld mandatory retirement of uniformed state police officers. In a per curiam opinion, the Court said its decisions "give no support to the proposition that a right of governmental employment per se is fundamental. . . . Accordingly, we have expressly stated that a standard less than strict scrutiny 'has consistently been 
strict scrutimy, however, where public employment hinges on a durational residence requirement. Smce the right to travel is affected, the specific interest restricted by such requirements need not itself be a fundamental right for strict scrutiny to be triggered. For exainple, Shapiro applied strict scrutiny because of the impact on the right of interstate travel, not because of a fundamental right to obtain welfare. ${ }^{47}$

The lower courts are spht on whether a durational residence requireinent for public employment "penalizes" the right to travel. 48 This Comment contends that a durational residence requirement which denies new residents equal consideration for government jobs constitutes a penalty on the exercise of the right to travel in three ways. First, access to einployinent in the new state is essential when a person exercises his right to travel there. Indeed, the Supreme Court has defined the right to travel as the right to "migrate, resettle, find a new job, and start a new life."49

Second, the recent migrant's interest in public employment is comparable to his interest in welfare, public housmg, ${ }^{50}$ and free medical services, exclusion from which has triggered strict scrutiny. Employment, like welfare, provides the means to obtain housing, inedical services, and other necessities. ${ }^{51}$ To deny a new migrant a government job, however, does not deny the right to work altogether. ${ }^{52}$ But in a tight

applied to state legislation restricting the availability of employment opportunities." " 427 U.S. at 313. In a dissenting opionion, Justice Marshall criticized this approacli: "Even if the right to eam a living does not include the right to work for the government, it is settled that because of the importance of the interest involved, we have always carefully looked at the reasons asserted for depriving a government employee of his job." Id. at 323 (footnote omitted).

47. There is no fundamental right to receive welfare. See Dandridge v. Williams, 397 U.S. 471,484 n.16 (1970).

48. The district court in Nehring v. Ariyoshi, 443 F. Supp. 228 (D. Hawaii 1977), concluded that "the denial of the opportunity to apply for public enployment does have a sufficient enough impact upon the right to travel to require that the statute be justified by a compelling state interest." Id. at 237. Since employment is the only way inost people can provide themselves with the necessities of life, excluding new residents from government jobs (12\% of the total job supply in Hawaii) is a penalty. Id. This brought the case under Shapiro and Memorial Hospital, rather than Sosna which "dealt with non-economic inatters which were not directly related to keeping people at or above the subsistence level." Id. Aceord, People ex rel. Holland v. Bleigh Constr. Co., 61 Ill. 2d 258, 270, 335 N.E.2d 469, 477 (1975).

However, in Town of Milton v. Civil Serv. Comm'n, 365 Mass. 368, 312 N.E.2d 188 (1974), the Massachusetts Supreme Judicial Court enployed the penalty analysis but came to the opposite conclusion. The court distinguished public enployment from the right to earn a living and minimized the burden of a mere preference on the individual's "means of obtaining life." Id. at 37273,312 N.E.2d at 192-93. Though it addressed the fundamental rights and necessities of life issues, it failed to explain why public employment was not a vital government benefit or privilege.

49. Meniorial Hosp. v. Maricopa County, 415 U.S. 250, 255 (1974) (quoting Shapiro v. Thompson, 394 U.S. at 629) (einphasis added).

50. Sce note 4 supra.

51. See Nehring v. Ariyoshi, 443 F. Supp. 228, 237 (D. Hawaii 1977).

52. See Town of Milton v. Civil Serv. Comm'n, 365 Mass. 368, 312 N.E.2d 188 (1974). But see Salla v. County of Monroe, 90 Misc. 2d 427, 395 N.Y.S.2d 366 (Sup. Ct. 1977), affd sub nom. 
job market, denial of public employment may leave a recent migrant witl few alternatives, just as denial of public loousing or free inedical services may leave him with few lousing or health care alternatives. This is especially true for those trained for work performcd primarily by government, such as police, fire, welfare, and recreation workers. ${ }^{53}$

Third, durational residence requirements for public einployment penalize exercise of the right to travel to a greater degree than the kind of requirements that have not triggered strict scrutiny. Denial of bar admission, for example, has inuch more limited real effects. ${ }^{54}$ While awaiting bar admission, an out-of-state attorney may still obtain legal einployment or compete favorably for alternative employinent. Moreover, potential lawyers are a much smaller class than are potential public employees. A higher tuition rate likewise works a lesser penalty than does denial of public employinent. A new resident who seeks public einployment is demied that employment by a durational residence requireinent, while one seeking a higher education is inerely forced to pay nore for it. ${ }^{55}$ Sosna einphasized that a durational residence requirement for divorce caused only a teinporary delay in what was sought. ${ }^{56}$ That could not be said, however, of a one-year denial of public einployment that causes a loss of the income and other benefits of that employment for the period.

\section{Purpose and Effect on Travel}

For these reasons, strict scrutimy should be apphed under a "penalty on the right to travel" analysis. However, today's Court might not follow this approach. It might focus on the intent to deter migration

Lisbon Contractors, Inc. v. County of Monroe, 43 N.Y.2d 985, 375 N.E.2d 1232, 404 N.Y.S.2d 843 (1978) (fundamental "right to work" triggered strict scrutiny of a durational residence requirement for public employment).

53. See Nehring v. Arioyshi, 443 F. Supp. 228, 237 (D. Hawaii 1977).

54. See Hawkins v. Moss, 503 F.2d 1171, 1179 (4th Cir. 1974), cert. denied, 420 U.S. 928 (1975) (outside parameters of penalty analysis); Suffling v. Bondurant, 339 F. Supp. 257, 258-60 (D.N.M. 1972), aff d mem. sub nom. Rose v. Bondurant, 409 U.S. 1020 (1972) (penalty analysis not applied).

55. See Hicklin v. Orbeck, 565 P.2d 159, 165 (Alas. 1977), rev'd on other grounds, 437 U.S. 518 (1978).

56. 419 U.S. 393, 406 (1975). The majority opinion explained:

Appellant was not irretrievably foreclosed from obtaining some part of what she sought, as was the case with the welfare recipients in Shapiro, the voters in Dunn, or the indigent patient in Maricopa County. She would eventually qualify for the same sort of adjudication which she demanded virtually upon her arrival in the State. Iowa's requirement delayed her access to the courts, but, by fulfilling it, she could ultimately have obtained the same opportunity for adjudication which she asserts ought to have been hers at an earlier poimt in time.

$I d$. at 406 . The dissent noted that the distinction therc between delay and permanent loss "ignores the severity of the deprivation suffered by the divorce petitioner who is forced to wait a year for relief." Id. at 421 . The year's wait may prevent remarriage and keep the spouses in an intolerable relationship. Id. at 422 . 
and the potential deterrent effect of a residence requirement im fixing the appropriate level of scrutiny. ${ }^{57}$

If the Court chooses to focus on intent, a public employment durational residence requirement designed to curb population growth would be more appropriate for strict scrutiny than one havmg only employment allocation objectives. If the Court requires a deterrent effect, that effect will be stronger in public employment cases than it was in cases (e.g., Sosna) in whicl strict scrutiny was not applied. Lower tuition and divorce are simply not necessities of life for inost people in the way a job is. Thus a waitmg period for public employment would inore strongly deter travel. A waiting period for bar admission, even assuming its effect on the decision to relocate is similar to one for public employment, affects many fewer people than one for public employment.

In sum, the penalty on recent interstate travel, the deterrent effect on migration, and in some cases the legislative imtent to deter migration justify the application of strict scrutimy to a durational residence requirement for public employment. Given the Supreme Court's apparent reluctance to extend strict scrutiny, lowever, an imtermediate test such as "substantial relation" is perhaps more likely to be applied. 58

\section{II}

\section{GOVERNMENTAL INTERESTS AND JUSTIFICATIONS}

Two broad justifications have been advanced for public employment durational residence requirements. First, it is claimed that they are needed to allocate public jobs to particular classes of peoplelonger-term, bona fide, or unemployed residents. ${ }^{59}$ Second, discour-

57. This is true notwithstanding Dunn v. Blumstein, 405 U.S. 330, 339-40 (1972). One reason is that Justice Rehnquist's views became prominent on the durational residence issue in Sosna. See text accoinpanying notes 39-41 supra. Moreover, lower court decisions have given weight to these factors. Sturgis v. Washington, 368 F. Supp. 38, 41 (W.D. Wash., 1973), affd mem., 414 U.S. 1057 (1973) (tuition); Chimento v. Stark, 353 F. Supp. 1211, 1218 (D.N.H. 1973), aff'd mem., 414 U.S. 802 (1973) (candidacy for state office); Starns v. Malkerson, 326 F. Supp. 234, 238 (D. Minn. 1970), aff' mem., 401 U.S. 985 (1971) (tuition). The Court's propensity to require legislative intent when analyzing equal protection issues, even when very important individual interests are at stake, was deinonstrated in Village of Arlington Heights v. Metropohtan Hous. Dev. Corp., 429 U.S. 252 (1977) (racial discrimination in housing) and Washington v. Davis, 426 U.S. 229 (1976) (racial discrimination in employment). (1974).

58. See Town of Milton v. Civil Serv. Comm'n, 365 Mass. 368, 377, 312 N.E.2d 188, 195

59. The interest in favoring long-term bona fide residents was asserted and rejected in Nehring v. Ariyoshi, 443 F. Supp. 228, 239 (D. Hawaii 1977) and Justice v. Manzagol, No. 74-611 (D.N.M. Jan. 20, 1976) (unpublished opinion). The interest in using such a requirement to alleviate unemployment was rejected in Hicklin v. Orbeck, 565 P.2d 159, 164-65 (Alas. 1977), rev"d on other grounds, 437 U.S. 518 (1978); State v. Wylie, 516 P.2d 142, 149-50 (Alas. 1973); Salla v. County of Monroe, 90 Misc. 2d 427, 429, 395 N.Y.S.2d 366, 368 (Sup. Ct. 1977), affd sub nom. 
agement of migration into an area will help control growth. ${ }^{60}$

These interests are obviously stronger than the "budgetary and recordkeeping" goals rejected in Shapiro, Dunn, and Memorial Hospital. ${ }^{61}$ But they also are distimguishable from the governmental interests which justified the durational residence requirements for divorce, ${ }^{62}$ lower tuition, ${ }^{63}$ bar admission, ${ }^{64}$ and candidacy for public office, ${ }^{65}$ and the nondurational residence requirements for public employment, ${ }^{66}$ all of which have been upheld.

Lisbon Contractors, Inc. v. County of Monroe, 43 N.Y.2d 985, 375 N.E.2d 985, 375 N.E.2d 1232, 404 N.Y.S.2d 843 (1978).

60. This justification was rejected in Nehring v. Ariyoshi, 443 F. Supp. 228, 238-39 (D. Hawaii 1977). Other justifications have been likewise rejected. See State v. Wylie, 516 P.2d 142, 150 (Alas. 1973) (improved civil service efficiency); York v. State, 53 Haw. 557, 559-61 \& n.3, 498 P.2d 644, 646-47 \& n.3 (1972) (greater familiarity with community); People ex rel. Holland v. Bleigh Constr. Co., 61 Ill. 2d 258, 270-71, 335 N.E.2d 469, 477 (1975) (greater tax contributions). The only justification accepted by a lower court was the particular interest in police work, Town of Milton v. Civil Serv. Comm'n, 365 Mass. 368, 374-76, 312 N.E.2d 188, 193-95 (1974).

61. See Sosna v. Iowa, 419 U.S. 393, 406-07 (1975). See also Nehring v. Airyoshi, 443 F. Supp. 228, 237 (D. Hawaii 1977).

62. Sosna upheld the divorce requirement on account of unique state interest in family law, the integrity of its own courts, and avoidance of conflict with other states. Sosna v. Iowa, 419 U.S. at 406-08 (1975). See note 7 supra.

63. The chief justification accepted by lower courts for the lower-tuition requirement has been educational cost equalization between residents "who, directly or indirectly, liave recently made some contribution to the econoiny of the state . . . one year prior to their attendance at a publicly financed institution of higher education" and those who have not. Kirk v. Regents of the Univ. of Cal, 273 Cal. App. 2d 430, 444, 78 Cal. Rptr. 260, 269 (1st Dist. 1969), appeal dismissed, 396 U.S. 554 (1970). Accord, Montgoinery v. Douglas, 388 F. Supp. 1139, 1145 (D. Colo. 1974), affd mem., 422 U.S. 1030 (1975); Sturgis v. Washington, 368 F. Supp. 38, 41 (W.D. Wash.) (threejudge court), aff'd mem., 414 U.S. 1057 (1973); Starns v. Malkerson, 326 F. Supp. 234, 241 (D. Minn. 1970) (three-judge court), aff'd mem., 401 U.S. 985 (1971). The Supreme Court expressly rejected this justification in dictum in Vlandis v. Kline, 412 U.S. 441,450 n.6 (1973), but las not articulated its basis for upholding durational residence requirements for lower tuition.

64. Such a requirement for bar admission has been justified by the state interest in the licensing process, especially assuring moral character and fitness. Suffiling v. Bondurant, $339 \mathrm{~F}$. Supp. 257, 259-60 (D.N.M. 1972), aff'd mem. sub nom. Rose v. Bondurant, 409 U.S. 1020 (1972). For most government positions, though, au extended period of residence for examination of an apphcant's fitness and moral character is unnecessary.

65. Suclı a requirement for candidacy to public office has been justified by the unique governmental interests involved. It (1) allows voters sufficient time to evaluatc a candidate's quahifcations, (2) assures that candidates will be familiar with the area's problems and needs, and (3) deters carpetbagging. See Sununu v. Stark, 383 F. Supp. 1287, 1290 (D.N.H. 1974), aff d mem., 420 U.S. 958 (1975).

66. At least seven governmental interests have been advanced for contimuous or bona fide residence requirenents for city cmployees. These include: (1) better community ethnic balance; (2) lower inncr city minority unemployment rates; (3) improved minority relations with city employees; (4) enhanced cmployce performance due to grcater knowledge of city conditions and a more personal stake in city progress; (5) reduced absenteeism and tardiness; (6) better emergency personnel availability; and (7) greater economic benefits simce inorc salaries would be spent locally. See Ector v. City of Torrance, 10 Cal. 3d 129, 135, 514 P.2d 433, 436, 109 Cal. Rptr. 849, 852 (1973). With the possible exception of (4), these interests can be achieved without waiting periods. As to justifications for a state nondurational residence requirement, see notes 13-14 and accoinpanying text supra. 
But can these state interests justify burdening the individual's right to travel and interest in coinpeting for public employment? Are such state interests coinpelling or even constitutionally permissible? Is a durational residence requirement precisely, substantially, or even rationally related to the objectives?

This Comment will examme these issues by applying the three-tier equal protection analysis to a one-year state residence requirement for public employinent. ${ }^{67}$

\section{A. Employment Allocation}

\section{Validity of the Purposes}

The Court has held that favoring older residents over newer ones, as an end in itself, is impermissible. Rejecting the asserted justification that older residents have contributed more to the community, Shapiro and Memorial Hospital held that public benefits and services could not be based on such past contributions. ${ }^{68}$ The equal protection clause prohibits distinction on such a basis, since it "would logically permit the State to bar new residents from schools, parks, and libraries or deprive thein of police and fire protection." 69 While Shapiro and Memorial Hospital dealt with justifications based on past tax contributions, the objections logically extend to apportioninent based on any contribution to or "prior claim" on the community. ${ }^{70}$

The state may claim other employment allocation objectives are indirectly served by a durational residence requireinent. It may claim that its purpose is to favor bona fide residents over nonresidents. ${ }^{71}$ Lower courts have given that purpose considerable support. ${ }^{72}$ How-

67. A state, rather than local, requirement will be discussed, simce it more clearly burdens the right of interstate travel. A one-year waiting period will be assumed for purposes of discussion.

68. Memorial Hosp. v. Maricopa County, 415 U.S. 250, 263-66 (1974); Shapiro v. Thompson, 394 U.S. 618, 632-33 (1969). See also Vlandis v. Kline, 412 U.S. 441, 450 n.6 (1973).

69. Shapiro v. Thompson, 394 U.S. 618, 632-33 (1969).

70. In Cole v. Housing Auth., 435 F.2d 807, 813 (1st Cir. 1970), older residents' "prior claim" on the city's charity was insufficient to sustain a two-year residence requirement for public housing. Relying on Shapiro, the court said that "the sentiment that [a two-year resident] is more a part of the community than a newcolner and has a higher claim to its bounty ...., even if permissible, does not rise to the level of compelling state imterest." The similar justification "that each community should take care of its own first" was found constitutionally impermissible eveu under the traditional equal protection test. King v. New Rochelle Mun. Hous. Auth., 442 F.2d 646, 649 (2d Cir.), cert. denied, 404 U.S. 863 (1971).

71. The reasoning would be that newer residents are less likely to be bona fide than older ones. Thus an outright exclusion of residents of less than one year's duration is a reasonable method of favoring bona fide residents.

72. Hicklin v. Orbeck, 565 P.2d 159 (Alas. 1977), rev'd, 437 U.S. 518 (1978); State v. Wylie, 516 P.2d 142, 150 (Alas. 1973); People ex rel. Holland v. Bleigh Constr. Co., 61 IIl. 2d 258, 271-73, 335 N.E.2d 469, $478-79$ (1975). But see Salla v. County of Monroe, 90 Misc. 2d 427, 429, 395 
ever, the Supreine Court's recent decision in Hicklin v. Orbeck ${ }^{73}$ viewed favoring residents as an invalid means of achieving employinent goals. At the same time, it did not expressly state that favoring residents was impermissible in itself. ${ }^{74}$ The state interest in aidimg unemployed residents who lack economic inobility or face cultural or linguistic impediments is stronger. For example, the Alaska Supreme Court recognized the state's "coinpelling" interest in reducing chronic unenuployment, particularly among native residents, and upgrading and more fully utilizing its human resources. ${ }^{75}$

Since favoring bona fide residents and unemployed ones in the allocation of public employinent are apparently valid ends, the question then is whether a durational residence requirenient is a proper means for achieving thein.

\section{Relationship of Means to Purposes}

a. Favoring Bona Fide Residents. Assuming in the wake of Hicklin that public einployment may be reserved for bona fide residents, a one-year residence requirenent seems to bear a rational (minimal) relationship to that purpose. It will effectively exclude many non-bona fide residents from public einployment. ${ }^{76}$

Such a requirement, however, could not survive a more rigorous test. Under a middle-tier "substantial relation" test, the requirenuent should be struck down. A nondurational bona fide residence requireinent would be just as effective in achieving the objective sought as a one-year requireinent. A state may claim that there is a "substantial" relationship between duration and bona fide residence or even that duration conclusively determines bona fide residence. But if a state inakes durational residence the crucial determinant of bona fide residence, it shows that its real purpose is to favor older residents over newer ones-an impermissible purpose under Shapiro and Memorial Hospital. ${ }^{77}$

If strict scrutiny apphies, a durational residence requirement

N.Y.S.2d 366, 368 (Sup. Ct. 1977), affd sub nom. Lisbon Contractors, Inc. v. County of Monroe, 43 N.Y.2d 985, 375 N.E.2d 1232, 404 N.Y.S.2d 843 (1978) ("protecting employınent opportumities of State residents against out-of-state residents is a constitutionally impermissible objective for State legislation," violating the commerce clause as well as equal protection).

73. See notes 13-14 supra.

74. 437 U.S. $518,526-28$ (1978).

75. State v. Wylie, 516 P.2d 142, 149-50 (Alas. 1973).

76. The rejection of duration as the determinant of bona fide residence in Shapiro, Dunn, and Memorial Hospital was, under strict scrutiny, not a rational relation test. See notc 78 and accompanying text infra.

77. See text accompanying notes 68-70 supra. In addition, if an intent to discriminate can be proved, the Court is more likely to apply strict scrutiny. See note 57 and accompanying text supra. 
should be invalidated because it favors bona fide residents in too crude a manner. Using length of residence as the determinant of bona fide residence harms many newcomers who are indeed bona fide residents. Shapiro, Dunn, and Memorial Hospital therefore rejected the use of duration as a convenient device or "rule of thumb" to determine residence or nonresidence conclusively. ${ }^{78}$ Even the use of duration as an irrebuttable presumption for college tuition purposes has been limited. ${ }^{79}$ While a durational requirement has been permitted for tuition and divorce purposes, ${ }^{80}$ it must be justified in its own right, not as a surrogate for bona fide residence. "In general, it is not very difficult . . . to determine on an individualized basis whether one recently arrived in the cominunity is in fact a resident, although of course there will always be difficult cases ...."

b. Helping the Unemployed. A durational residence requireinent for public employment is rationally related to helping unemployed residents, since it does favor them over potential competitors from out of state. However, this justification would fall under an intermediate standard of review. The Supreme Court concluded in Hicklin that even a nondurational residence requirement is not substantially related to helping the unemployed. ${ }^{82}$

78. Dunn v. Blumstein, 405 U.S. 330, 349-51 (1972); Shapiro v. Thompson, 394 U.S. 618, 636 (1969). In Memorial Hosp. v. Maricopa County, 415 U.S. 250, 267 (1974) (footnote omitted), the Court summarized the reasons rejecting this approach:

Besides not being factually defensible, this test is certainly overbroad to accomplish its avowed purpose. A mere residence requirement would acomplish the objective of limiting the use of public medical facilities to bona fide residents of the County without sweeping within its prohibitions those bona fide residents who had moved into the State within the qualifiymg period. Less drastic means, which do not impinge on the right of interstate travel, are available and employed to ascertain an mdividual's true intentions, without exacting a protracted waiting period which may have dire economic and health consequences for certain citizens.

79. Vlandis v. Kline, 412 U.S. $441,451-52$ (1973).

80. Sosna v. Iowa, 419 U.S. 393 (1975); Vlandis v. Kline, 412 U.S. 441 (1973).

81. Dunn v. Blumstein, 405 U.S. 330, 351 (1972). The Alaska Supreme Court has suggested alternative means to determine bona fide residence, such as maintenance of a place of residence $\mathrm{m}$ the state, no claim of residence elsewhere, residence for voting purposes, and intent to be a permanent resident as shown by "all attending circumstances." Hicklin v. Orbeck, 565 P.2d 159, 165 (Alas. 1977), rev'd on other grounds, 437 U.S. 518 (1978). Other relevant factors include estabhshment of local bank accounts, change of driver's license or automobile registration, children's residence and their enrollment in local schools, ownership of a lome or other real property, and local einployment. See Hawk v. Fenner, 396 F. Supp. 1, 8 (D.S.D. 1975) (criteria suggested for establishing bona fide residence for welfare purposes).

82. As Justice Breunan explamed for the Court:

Alaska Hire simply grants all Alaskans . . . a fiat employment preference for all jobs covered by the Act. A highly skilled and educated resident who has never been uneinployed is entitled to precisely the saine preferential treatinent as the unskilled, habitually unemployed Arctic Eskimo enrolled in a job-training program. If Alaska is to attempt to ease her unemployment problem by forcing employers within the State to discriminate against nonresidents-again, a pohicy which may present serious constitutional ques- 
Obviously, then, such a justification falls under strict scrutiny. The requirement is not tailored to assist residents with employment mobility barriers. It gives all one-year residents an absolute advantage over newer ones. It thereby favors many who meet the residence requirement and have no uneinployment probleins. At the same time, it excludes natives or other long-time residents of the state who moved away, lost their residency, and later returned. Furthermore, a durational residence requireinent fails to deal with the underlying causes of unemployment, such as inadequate education or training, or insufficient job opportunities in certain geographical areas. ${ }^{83}$ It would be less drastic and more effective to prefer only those persons with einployment problems regardless of their length of residence. ${ }^{84}$

As an employment allocation ineasure, then, a one-year residence requirement probably can survive a rational relation test, but clearly falls under an intermediate substantial relation standard or strict scrutiny. It bears a rational, but insubstantial, relationship to the purposes of allocating public employinent to bona fide residents and of favoring uneinployed residents. Such a requirement clearly is not precisely drawn to achieve those purposes with the least drastic burden on the right of interstate travel. Moreover, no kind of residence requirement designed to aid those with uneinployinent problems will serve well. Either requirement will benefit many who do not need help and dilute the benefit to those who do. To help the real target groups would require (1) a inuch longer waiting period that would increase the penalty on the right to travel; (2) a preference system pegged to need not duration; or (3) programs to enhance the target's employability.

\section{B. Growth Control}

In Nehring v. Ariyoshi, Hawaii advanced the novel justification that a durational residence requireinent for public einployinent helped "control growth and protect Hawaii's unique island environment." 85 The federal district court held that the state failed to establish a compelling state interest or even a rational basis for the requireinent. ${ }^{86} \mathrm{Al}-$ though a stronger factual showing could satisfy the rational basis

tions-the means by which she does so must be more closely tailored to aid the unemployed the Act is intended to benefit.

Hicklin v. Orbeck, 437 U.S. 518, 527-28 (1978). While the Court's conclusion in Hicklin was in the context of a privileges and immunities challenge to a simple residency preference, the reasoning extends by analogy to a one-year residence requirement. Neither provision favors the unemployed over the bulk of their competition, namely other one-year residents.

83. State v. Wylie, 516 P.2d 142, 149-50 (Alas. 1973).

84. Hicklin v. Orbeck, 565 P.2d 159, 165 (Alas. 1977), rev'd on other grounds, 437 U.S. 518 (1978).

85. 443 F. Supp. 228, 238 (D. Hawaï 1977).

86. Id. at 239. 
standard ${ }^{87}$ rejection of the growth control argument was correct in any event.

\section{Validity of the Purpose}

The court in Nehring acknowledged that coping with future growth posed substantial problems but concluded that Hawaii could not constitutionally attempt to keep people out of the state. ${ }^{88}$ It rehied on Supreine Court statements rejecting other deliberate attempts to discourage migration by imposing durational residence requirements. The Court in Shapiro said that deterring indigent immigration was impermissible since if a law has "no other purpose . . . than to chill the assertion of constitutional rights by penalizing those who choose to exercise them, then it [is] patently unconstitutional." ${ }^{\text {"99 }}$ Memorial Hospital reiterated that the purpose of inhibiting immigration generally is constitutionally impermissible. ${ }^{90}$

Three decades before, the Court had struck down a law which directly prohibited bringing indigents into California. "The social phenomenon of large-scale interstate migration" was a national concern that cannot be treated diversely by the states, notwithstanding "problems of health, morals and especially finance, the proportions of which are staggering." 11

It may be argued, however, that land use and zoning cases show growth control to be a constitutionally permissible objective. In Village of Belle Terre v. Boraas the Supreme Court found the police power

87. In Nehring, "none of the witnesses called by the state could testify as to any significant connection between the number of people moving into Hawaï who were planning to or would take public jobs and the enviroumental problems faced by the state. Indeed, they had not even studied this problem. No one could even inform the court as to the . . . number of public employees who had been residents of Hawaii for less than a year." Id. at 238-39.

88. Id. at 238.

89. Shapiro v. Thompson, 394 U.S. 618, 631 (1969).

90. 415 U.S. 250, 263-64 (1974). In the one Supreme Court opinion upholding a durational residence requirement (for obtaining a divorce), there was no deliberate attempt to deter inigration. Sosna v. Iowa, 419 U.S. 393 (1975). See note 7 supra. Cases upholding such requirements for college tuition emphasized that there was no intent to deter migration. Sturgis v. Washington, 368 F. Supp. 38, 40 (W.D. Wasl. 1973), aff d mem., 414 U.S. 1057 (1973); Starns v. Malkerson, 326 F. Supp. 234, 241 (D. Minn. 1970), affd mem., 401 U.S. 985 (1971); Kirk v. Regents of the Umiv. of Cal., 273 Cal. App. 2d 430, 440, 78 Cal. Rptr. 260, 267 (1969), appeal dismissed, 396 U.S. 554 (1970). In cases dealing with public and bar admission requirements, different state purposes were asserted. See notes 41 \& 50 supra.

91. Edwards v. California, 314 U.S. 160, 175-76 (1941). The Court said:

It is frequently the case that a State inight gain a momentary respite from the pressure of events by the siniple expedient of shutting its gates to the outside world. But, in the words of Mr. Justice Cardozo: "The Constitution was framed under the dominion of a political philosophy less parochial in range. It was framed upon the theory that the peoples of the several states must sink or swim together, and that in the long run prosperity and salvation are in umion and not division."

Id. at 173-74 (citation omitted). 
ample to protect "the blessings of quiet seclusion." 92 In Village of Euclid v. Ambler Realty Co. the Court held that the police power permitted a mumicipality to restrict natural development to protect community health and safety. ${ }^{93}$

However, these statements about land use controls were not made in the context of the right to travel under an equal protection challenge. Euclid and Belle Terre were responses to local efforts which involved no intent to deter interstate migration as such. But where such a dehiberate statewide atteinpt is inade through residence requirements, the equal protection and right to travel doctrines of Shapiro and Memorial Hospital should govern. Under these doctrines, a purpose to inhibit migration would be difficult to sustain as legitimate. And under strict scrutimy, the state inust establish not only a legitimate end but a compelling imterest. A state's mterest in deterring immigration should not be compelling unless the state proves that its resource and population probleins are urgent and considerably inore so than those of other states that would retain the population deterred from migrating.

Finally, a durational residence requirement assertcd to be a real growth control device may in fact be a political ruse used to foster an illusion that outsiders can be kept out. The courts will not and should not approve such an effort. ${ }^{94}$ The goal of promoting provincial prejudices to favor long-term residents is wholly impermissible "under a Constitution which was written partly for the purpose of eradicatimg such provincialism."95

\section{Relationship of Means to Purpose}

Since deterring interstate migration probably is an invalid purpose, the use of a public employment durational residency requireinent to achieve that purpose fails even a rational basis test. Assuming, arguendo, that the purpose is legitimate, such a requirement may satisfy the

92. 416 U.S. 1,9 (1974).

93. 272 U.S. 365, 389-90 (1926). But see Steel Hill Dev., Inc. v. Town of Sanbornton, 469 F.2d 956, 960 (1st Cir. 1972); Construction Indus. Ass'n v. City of Petaluma, 375 F. Supp. 574, 586 (N.D. Cal. 1974), rev'd, 522 F.2d 897 (9th Cir. 1975), cert. denied, 424 U.S. 934 (1976); Appeal of Kit-Mar Builders, Inc., 439 Pa. 466, 472-76, 268 A.2d 765, 768-69 (1970); National Land and Inv. Co. v. Kohn, 419 Pa. 504, 531-33, 215 A.2d 597, 612 (1965).

94. In Memorial Hosp. v. Maricopa County, 415 U.S. 250, 266 (1974), the Supreme Court said that a state "may not enploy an invidious discrimination to sustain the political viability of its programs." The Court rejected the argument that a durational residence requirement was perceived by the public (voters) as assurance that low-income families would not be attracted by the county hospital and was, therefore, needed to maintain public support of the hospital. Id. The United States Court of Appeals for the First Circuit rejected a similar political attempt to create an appearance that a residence requirement for public lousing would deter migration. Cole $v$. Housing Auth., 435 F.2d 807, 812 (1st Cir. 1970).

95. Cole v. Housing Auth., 435 F.2d at 813 . 
rational basis test, ${ }^{96}$ but because its impact on growth is speculative at best, ${ }^{97}$ it has an insufficient connection with the purpose to satisfy an intermediate substantial relation test.

Under strict scrutiny, even assuming that a state could show a compelling imterest in deterring migration, a one-year residency requirement for public employinent is not precisely tailored to achieve growth control objectives. While its deterrent effect is speculative, it will surely penalize some recent migrants who would have moved to a state regardless of such requirements. Nor will a durational residency requirement minimize the burden on constitutional rights. The state can "constitutionally seek to control growth through the use of zoning and other, inore enlightened tools of economic planning."98

\section{CONCLUSION}

The Supreme Court has not yet addressed the issue of durational residence requirements for public einployment but may be presented such a case soon, as states and localities step up efforts to deal with unemployment and population growth. The Court has both upheld and rejected such requirements in other contexts. In its most recent right to travel opinion, Sosna, it has ignored Shapiro's right to travel "penalty analysis," but, in Hicklin, also showed renewed opposition to residence requirements.

Notwithstanding the Court's weakening of protection of the right to travel and its wavering treatment of durational residence requirements since Shapiro, this Cominent argues that such requirements for public employment are unconstitutional.

Durational residence requirements for public employment penalize exercise of the right to travel. For a recent migrant, potential public employment can be a vital governmental benefit or privilege approaching the importance of welfare, public housing, and nonemergency inedical care. Denial of public employment based on length of residence also penalizes the recent exercise of the right to travel to a greater degree than such requirements upheld for divorce, college tuition, bar ad-

96. The state's factual showing in Nehring failed to persuade the district court that the oneyear residence requirement was even rationally related to the state's environmental goals. See note 87 supra.

97. The deterrent effect of such a requirement may often be slight. In the context of $\mathrm{Nehr}$ ing, Hawaii's State Personnel Director conceded that "very few" newcomers sought state jobs. Honolulu Star-Bulletin, Aug. 29, 1977, at 1. Therefore, the waiting period would have deterred few people from moving to Hawaii.

98. Nehring v. Ariyoshi, 443 F. Supp. 228, 238 (D. Hawaii 1977). See generally Bosselman, Growth Management and Constitutional Rights-Part I: The Blessings of Quiet Seclusion, 8 URB. LAW. 3, 35 (1972); Ellickson, Suburban Growth Controls: An Economic and Legal Analysis, 86 YALE L.J. 385 (1977); Znmbrun and Hookano, No-Growth and Related Land-Use Legal Problems: an Overview, 9 URB. LAw. 122 (1977). 
mission, and candidacy for public office. Under the penalty analysis of the Shapiro/Memorial Hospital line of cases, a durational residency requirement for public employment should therefore be subjected to strict equal protection scrutimy. If not, an intermediate "substantial relation" test should apply, given the importance of the imdividual interests in public employment and the fundamental right to travel.

The governmental justifications discussed $\mathrm{m}$ this Comment cannot sustain such requirements for public employment under either standard. First, as to employment allocation, either the purposes or the means are improper. The purpose of favoring longer-terin residents over other residents is constitutionally impermissible. For the purpose of favoring a state's bona fide residents over nonresidents in public employment, a durational residence requirement is too broad. A nondurational bona fide residence requirement is a more appropriate and specifically designed tool for this purpose, assuming even this is permissible after Hicklin. A durational residence requirement is even less tailored or substantially related to the purpose of alleviating unemployment. Achievement of this purpose requires more specific preference systems and affirmative programs, not simply excluding new residents.

Sucl a requirement for public employment is also mvalid as a device for deterring migration and curbing population growth. The purpose itself probably is impermissible, and the relationship between the purpose and the residence requirement is neither precise nor substantial. Population growth control sliould be sought through means which are less constitutionally offensive and more effective.

Michael A. Lee*

* A.B. 1965, M.A. 1967, University of California, Los Angeles; third-year student, Boalt Hall School of Law. 